\title{
OBSERVATION ON LARVAL DEFORMITY DURING INDUCED SPAWNING OF WALKING CATFISH, CLARIAS BATRACHUS (ACTINOPTERYGII: SILURIFORMES: CLARIIDAE), AT DIFFERENT COMBINATIONS OF HUMAN CHORIONIC GONADOTROPIN DOSE AND LATENCY PERIOD
}

\author{
Sangram K. SAHOO*, Shiba S. GIRI, Suresh CHANDRA, and Ashok K. SAHU \\ Central Institute of Freshwater Aquaculture, Kausalyaganga, \\ Bhubaneswar - 751 002, Orissa, India
}

Sahoo S.K., Giri S.S., Chandra S., Sahu A.K. 2009. Observation on larval deformity during induced spawning of walking catfish, Clarias batrachus (Actinopterygii: Siluriformes: Clariidae), at different combinations of human chorionic gonadotropin dose and latency period. Acta Ichthyol. Piscat. 39 (1): 43-45.

\begin{abstract}
Five combinations of human chorionic gonadotropin (hCG) dose and five latency periods were evaluated to observe the pattern of deformed larvae among the hatchlings in walking catfish, Clarias batrachus (L.). A higher percentage (7\%-12\%) of deformed larvae were observed at 1000, 2000, and $5000 \mathrm{IU} \cdot \mathrm{kg}^{-1}$ with $14-23 \mathrm{~h}$ latency combinations. The results of the study indicated that $3000 \mathrm{IU} \cdot \mathrm{kg}^{-1}$ with $14-23 \mathrm{~h}$ and $4000 \mathrm{IU} \cdot \mathrm{kg}^{-1}$ with 14-17 h latency combinations were preferable to reduce the deformed larvae $(4 \%-6 \%)$ among the hatchlings during induced spawning of the catfish.
\end{abstract}

Keywords: Clarias batrachus, deformed larvae, latency period, human chorionic gonadotropin, hCG

The walking catfish, Clarias batrachus (L.), is a potential species for aquaculture. Its production has been documented at few occasions (Areerat 1987, Thakur and Das 1986). Availability of quality seed is one of the important pre-requisites for successful culture of any species. So induced spawning is always advisable for getting optimum quantity and quality of the stocking material.

The breeding performance and egg quality of C. batrachus has been reported by the use of different dose of inducing agents with latency combinations in several occasions (Zonneveld et al. 1988, Sahoo et al. 2005, 2007). The deformed larvae like bend trunk and tail, acephalic and tunicate larvae are often encountered along with the normal larvae during breeding operations in carp (Rath et al. 1995) and catfish (Sahoo et al. 2004). The quantity of deformed larvae in Silurus glanis was observed as high as $50 \%$ during hatchery production (Linhart and Billard 1995). The deformity in larvae is originated due to poor egg quality, impact of environment or due to fertilization of over-ripped eggs. The over-ripening of eggs occurs due to delayed in stripping of ovulated eggs. This condition is sometimes happened while working in the hatchery condition. The increase in number of deformed larvae affects the production, quality of larvae and the profitability of a hatchery. No information is available on the pattern of deformed larval production while using human chorionic gonadotropin (hCG) as an inducing agent during induced breeding of $C$. batrachus. Hence the present study is aimed to communicate the pattern of deformity among the hatchlings during its induced spawning at different dose of hCG and latency period combinations.

C. batrachus broods were raised in earthen ponds (0.01 ha) at the Institute and were fed with pelleted feed containing $30 \%$ crude protein at $2 \%$ of their body weight, daily. The female broods of 120-130 g weight range were selected for induced breeding during July-August. The female broods were selected as suggested earlier (Sahoo et al. 2005). The hCG was purchased and reconstituted in $1 \mathrm{~mL}$ of solvent provided with the pack. That was further diluted with normal saline solution to get required concentrations of injectable hCG. The groups of females were injected with 1000, 2000, 3000, 4000, and 5000 IU hCG per kg body weight, and stripped after five latency periods, $11,14,17,20$, and $23 \mathrm{~h}$ in $25(5 \times 5)$ different combinations. Each group of fish comprised of five females and, was considered for each dose level and latency period combination.

The testes were removed from three male fish, incised and squashed in normal saline solution $(0.89 \% \mathrm{NaCl})$ to get sperm suspension. A drop of sperm suspension was

\footnotetext{
${ }^{*}$ Correspondence: Dr Sangram K. Sahoo, Central Institute of Freshwater Aquaculture, Kausalyaganga, Bhubaneswar - 751 002, Orissa, India, phone: 91-674-2465446, fax: 91-674-2465407, e-mail: sksahoo100@rediffmail.com
} 
checked under microscope for sperm motility only once of every time before fertilizing the eggs of the female exposed to particular latency and dose combination. The motility of the sperm was initiated by the use of water supplied to hatchery and was found to be more than $80 \%$. At the end of desired latency periods the eggs of individual females were stripped into clean dry plastic Petri dishes.

From each female, three samples of $300 \mathrm{mg}$ egg were weighed to its nearest $\mathrm{mg}$ and the individual samples were mixed gently with 4-5 drops of sperm suspension. Thereafter the eggs were washed thoroughly with water and released into the plastic incubation tray of 5-L capacity, provided with flow through of water $\left(0.2 \mathrm{~L} \cdot \mathrm{min}^{-1}\right)$ till hatching. After complete hatchings, the total number of deformed larvae was counted among the total hatchling on the basis of bent trunk and tail, short tail, headless and rudimentary tail. The mean deformed larvae in triplicate trays were recorded and expressed as percent of deformed larvae per female. The mean percent of deformed larvae in all five females was considered as the rate of deformed larvae under a particular latency period and hormone dose combination.
Hatchery water temperature, $\mathrm{pH}$ and dissolved oxygen were $27-28.5^{\circ} \mathrm{C}, 6.8-7.5$ and $5.8-6.7 \mathrm{ppm}$, respectively. Statistical analysis of the data was performed using twoway analysis of variance (Snedecor and Cochran 1967) that included effects due to the dose of inducing agent and latency period. Treatment effects were considered significant at $P<0.05$.

The percentage of deformed larvae among the hatchlings during induced spawning of $C$. batrachus at various doses of hCG and latency periods is presented in Table 1. There were no deformed larvae found in females injected with 1000-5000 IU $\cdot \mathrm{kg}^{-1}$ and stripped at $11 \mathrm{~h}$ post-injection, since the eggs did not hatch. Whereas the deformed larvae (Figs. 1, 2) were observed in all other combinations during induced spawning and they appeared as high as $11 \%-12 \%$ in certain combinations. The injection of low dose $\left(1000\right.$ and $\left.2000 \mathrm{IU} \cdot \mathrm{kg}^{-1}\right)$ to female fish and stripping at 14-23 h post-injection produced higher percentage of deformed larvae, which were similar to each other $(P<0.05)$. At these combinations, it was difficult to strip the females indicating incomplete ovulation. The ejection of

Pattern of deformed larvae percentage among the hatchlings during induced spawning of Clarias batrachus at different dose of hCG and latency period combinations

\begin{tabular}{|c|c|c|c|c|c|}
\hline \multirow{2}{*}{$\begin{array}{l}\text { Latency } \\
\text { period }[\mathrm{h}]\end{array}$} & \multicolumn{5}{|c|}{ hCG per kg of body weight } \\
\hline & $1000 \mathrm{IU}$ & $2000 \mathrm{IU}$ & $3000 \mathrm{IU}$ & $4000 \mathrm{IU}$ & $5000 \mathrm{IU}$ \\
\hline 11 & $0^{\mathrm{a}}{ }_{\mathrm{w}}^{\mathrm{a}}$ & $0^{\mathrm{a}}{ }_{\mathrm{w}}$ & $0^{\mathrm{a}}{ }_{\mathrm{w}}$ & $0^{\mathrm{a}}{ }_{\mathrm{x}}$ & $0^{\mathrm{a}}{ }_{\mathrm{w}}$ \\
\hline 14 & $8.60 \pm 3.60^{\mathrm{a}}{ }_{\mathrm{v}}$ & $8.00 \pm 2.04^{\mathrm{a}}{ }_{\mathrm{v}}$ & $5.20 \pm 0.58^{\mathrm{ab}}{ }_{\mathrm{v}}$ & $4.20 \pm 0.37^{\mathrm{b}}{ }_{\mathrm{w}}$ & $9.60 \pm 0.50^{\mathrm{a}}{ }_{\mathrm{v}}$ \\
\hline 17 & $7.40 \pm 3.02^{\mathrm{ab}}{ }_{\mathrm{v}}$ & $7.60 \pm 1.96^{\mathrm{ab}}{ }_{\mathrm{v}}$ & $6.20 \pm 0.48^{\mathrm{b}}{ }_{\mathrm{v}}$ & $4.60 \pm 0.67^{\mathrm{b}}{ }_{\mathrm{w}}$ & $10.60 \pm 0.50^{\mathrm{a}}{ }_{\mathrm{v}}$ \\
\hline 20 & $9.40 \pm 2.44_{\mathrm{v}}^{\mathrm{a}}$ & $8.80 \pm 0.66^{\mathrm{a}}{ }_{\mathrm{v}}$ & $5.00 \pm 0.31^{\mathrm{b}}{ }_{\mathrm{v}}$ & $8.40 \pm 0.50^{\mathrm{ab}}$ & $11.20 \pm 1.11^{\mathrm{a}}{ }_{\mathrm{v}}$ \\
\hline 23 & $8.00 \pm 2.02^{\mathrm{ab}}{ }_{\mathrm{v}}$ & $9.00 \pm 0.70_{\mathrm{v}}^{\mathrm{ab}}$ & $5.40 \pm 0.50^{\mathrm{b}}{ }_{\mathrm{v}}$ & $10.00 \pm 0.50^{\mathrm{a}}{ }_{\mathrm{v}}$ & $11.80 \pm 0.80^{\mathrm{a}}{ }_{\mathrm{v}}$ \\
\hline
\end{tabular}

The value bearing different superscripts in the row differs significantly $(P<0.05)$; The value bearing different subscripts in the column differ significantly $(P<0.05)$.

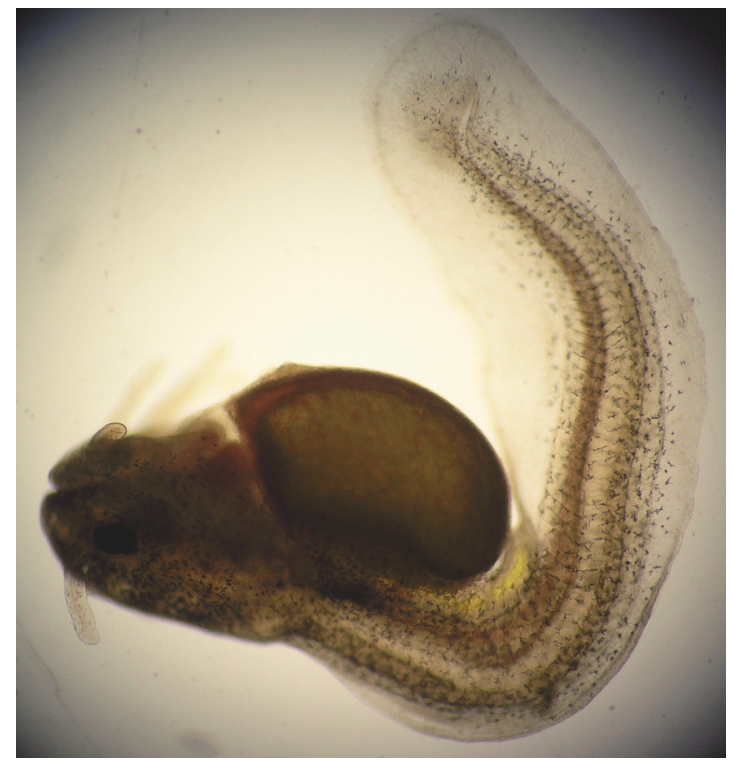

Fig. 1. Clarias batrachus hatchling showing bend trunk

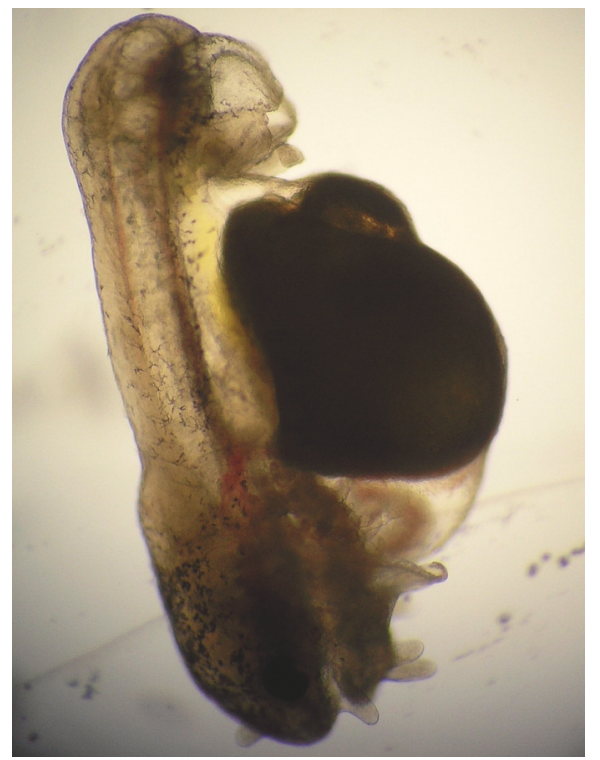

Fig. 2. Clarias batrachus hatchling showing fused tail 
unripe eggs cannot be ruled out during the stripping of incomplete ovulated females. So the production of abnormal larvae at these combinations might have originated due to fertilization of unripe ova, which agrees to the previous report (Richter and van den Hurk 1982). In a separate study, higher percentage of deformed larvae was also appeared while injecting lowest dose of an inducing agent in this catfish during spawning induction (Sahoo et al. 2005). The higher percentage of abnormal larvae ranging from $8 \%-12 \%$ was also observed when the females were injected 4000 and $5000 \mathrm{IU} \cdot \mathrm{kg}^{-1}$, and stripped at $20-23 \mathrm{~h}$ and 14-23 h post-injection respectively. The eggs obtained by stripping in these combinations might have remained longer period in ovocoel after ovulation. These ovulated eggs were also exposed to hypoxic condition, led to over ripening (Ohta et al. 1996). Hence the high fraction of abnormal larvae at these combinations may have originated from fertilization of over-ripped eggs in this catfish, as also reported in Pangasianodon hypophthalmus (cf. Legendre et al. 2000) and Silurus glanis (cf. Linhart and Billard 1995). The reduction in permeability of essential ions (Lam et al. 1978), error in the chromosomal distribution (Saito et al. 1993), and chromosomal aberration (Yamazaki et al. 1989) are some of the causes reported during aging phenomenon responsible for abnormal larval production. As few as $4 \%-5 \%$ of deformed larvae were observed when the female was injected with 4000 IU hCG and stripped at 14-17 h post-injection. The deformed larval production was also $5 \%-6 \%$ only at 3000 IU dose for an extended period of $23 \mathrm{~h}$ latency.

In practice, it is therefore recommended that the hCG injection of $3000-4000 \mathrm{IU} \cdot \mathrm{kg}^{-1}$ body weight in combination with $14-17 \mathrm{~h}$ post-injection is the best to reduce the possibilities of over-ripening of ovulated eggs. Further prolonging of latency up to $23 \mathrm{~h}$ at $3000 \mathrm{IU}$ hCG dose will be helpful to get reduced number of deformed larvae during breeding operation. So fertilization of ovulated eggs obtained in these combinations ensures larger number of normal larvae production during spawning induction.

\section{ACKNOWLEDGEMENT}

The authors are thankful to Director, CIFA, Kausalyaganga, Bhubaneswar for providing facilities to conduct this experiment.

\section{REFERENCES}

Areerat S. 1987. Clarias culture in Thailand. Aquaculture 63: 355-362. DOI: 10.1016/0044-8486(87)90084-6.

Lam T.J., Nagahama Y., Chan K., Hoar W.S. 1978. Overripe eggs and postovulatory corpora lutea in the threespine stickleback, Gasterosteus aculeatus L., form trachurus. Canadian Journal of Zoology 56: 2029-2036. DOI: 10.1139/z78-273.

Legendre M., Slembrouck J., Subagja J., Kristanto A.H. 2000. Ovulation rate, latency period and ova viability after GnRH- or hCG-induced breeding in the Asian catfish Pangasius hypophthalmus (Siluriformes, Pangasiidae).
Aquatic Living Resources 13: 145-151. DOI: 10.1016/ /S0990-7440(00)00148-0.

Linhart O., Billard R. 1995. Survival of ovulated oocytes of the European catfish (Silurus glanis) after in vivo and in vitro storage or exposure to saline solutions and urine. Aquatic Living Resources 8: 317-322. DOI: 10.1051/alr:1995033.

Ohta H., Kagawa H., Tanaka H., Okuzawa K., Hirose K. 1996. Changes in fertilization and hatching rates with time after ovulation induced by 17, 20ß-dihydroxy-4-pregnen-3-one in the Japanese eel, Anguilla japonica. Aquaculture 139: 291-301. DOI: 10.1016/0044-8486(95)01167-6.

Rath S.C., Gupta S.D., Dasgupta S. 1995. Common embryonic abnormalities of Indian major carps bred in indoor hatchery systems. Journal of Aquaculture in the Tropics 10: 193-199.

Richter C.J.J, van den Hurk R. 1982. Effects of 11-desoxycorticosterone-acetate and carp pituitary suspension on follicle maturation in the ovaries of the African catfish, Clarias lazera (C.\&V.). Aquaculture 29: 53-66. DOI: 10.1016/0044-8486(82)90033-3.

Sahoo S.K., Giri S.S., Chandra S., Sahu A.K. 2007. Spawning performance and egg quality of Asian catfish Clarias batrachus (Linn.) at various doses of human chorionic gonadotropin (hCG) injection and latency period during spawning induction. Aquaculture 266: 289-292. DOI: 10.1016/j.aquaculture.2007.02.006.

Sahoo S. K., Giri S.S., Sahu A.K. 2005. Effect on breeding performance and egg quality of Clarias batrachus (Linn.) at various doses of Ovatide during spawning induction. Asian Fisheries Science 18: 77-83.

Sahoo S.K., Giri S.S., Swain T., Sahu A.K. 2004. Observations on some common abnormalities in induced bred Clarias batrachus hatchlings. Journal of Inland Fisheries Society of India 36: 67-71.

Saito H., Koike K., Saito T., Nohara M., Kawagoe S., Hiroi M. 1993. Aging changes in the alignment of chromosomes after human chorionic gonadotropin stimulation may be a possible cause of decreased fertility in mice. Hormone Research 39 (Suppl. 1): 28-31. DOI:10.1159/000182754.

Snedecor G.W., Cochran W.G. 1967. Statistical methods. Iowa State University Press, Ames IA, USA.

Thakur N.K., Das P. 1986. Synopsis of biological data on magur, Clarias batrachus (Linnaeus, 1785). CIFRI, Bulletin No 41: 1-42.

Yamazaki F., Goodier J., Yamano K. 1989. Chromosomal aberrations caused by ageing and hybridization in charr, masu salmon and related salmonids. Physiology and Ecology of Japan 1: 529-542.

Zonneveld N., Rustidja,Viveen W.J.A.R., Maduna W. 1988. Induced spawning and egg incubation of the Asian catfish, Clarias batrachus. Aquaculture 74: 41-47. DOI: 10.1016/0044-8486(88)90084-1.

Received: 12 October 2007

Accepted: 5 January 2009

Published electronically: 20 May 2009 